\title{
QUEEN'S
UNIVERSITY
BELFAST
}

\section{Resonance Microwave Reflectometry for High-Resolution Surface Imaging}

Malyuskin, O., \& Fusco, V. (2015). Resonance Microwave Reflectometry for High-Resolution Surface Imaging. 1. Paper presented at URSI AT-RASC 1st URSI Atlantic Radio Science Conference, Gran Canaria, Spain. http://www.at-rasc.com/

\section{Document Version:}

Peer reviewed version

Queen's University Belfast - Research Portal:

Link to publication record in Queen's University Belfast Research Portal

Publisher rights

Copyright 2015 The Authors

\section{General rights}

Copyright for the publications made accessible via the Queen's University Belfast Research Portal is retained by the author(s) and / or other copyright owners and it is a condition of accessing these publications that users recognise and abide by the legal requirements associated with these rights.

Take down policy

The Research Portal is Queen's institutional repository that provides access to Queen's research output. Every effort has been made to ensure that content in the Research Portal does not infringe any person's rights, or applicable UK laws. If you discover content in the Research Portal that you believe breaches copyright or violates any law, please contact openaccess@qub.ac.uk. 


\title{
Resonance Microwave Reflectometry for High-Resolution Surface Imaging
}

\author{
Oleksandr Malyuskin*, Vincent Fusco \\ The Institute of Electronics, Communications and Information Technology \\ Queen's University Belfast, BT3 9DT, UK, http://www.ecit.qub.ac.uk/
}

\begin{abstract}
Novel high-resolution near field imaging technique based on microwave resonance reflectometry is presented. Two types of microwave resonance probes are considered - a small helix antenna and a resonantly loaded aperture in conductive screen. It is shown that these probes possess the electromagnetic (EM) characteristics essential for high-resolution near field imaging device: (i) they enable very tight near field collimation with full width at half maximum less than $\lambda / 10, \lambda$ is a wavelength of radiation; (ii) the probes near field coupling to the imaged samples is based on the high-quality resonance energy transmission which allows their operation at very low excitation power level with high receive signal-tonoise ratio. Additionally, the resonance nature of these probes enables accurate microwave spectroscopic characterization of a wide range of dielectric materials. To the best of the authors' knowledge resonance microwave probes of considered types have never been applied to near field imaging before.
\end{abstract}

In the talk the second-to-none resolution properties of the proposed technique are demonstrated in various near field imaging scenarios involving conductive printed elements/printed antennas, dielectric structures, surface defects and biomaterials. Particularly, it is shown that the typical resolution contrast between the subwavelength metal and/or dielectric structures (for quarter-wavelength or smaller features) in raw reflection images is more than $10 \mathrm{~dB}$ in amplitude and 100 degrees in phase over the range of standoff distances $\lambda / 20-\lambda / 10$. For comparison, most existing near field probes based on the open-ended coaxial cables or open-ended waveguides exhibit prohibitively low resolution contrast, within $\sim 1-2 \mathrm{~dB}$ range.

A correlation-based image processing technique which permits detection of subwavelength defects (with characteristic size less that $\lambda / 20$ ) with extremely high resolution contrast (more than $20 \mathrm{~dB}$ ) in periodic printed structures is also discussed and illustrated using experimental data.

Additionally, an artificial dielectric skin model is developed to show the potential of the proposed technique in early stage skin cancer identification. Highly accurate EM discrimination between malignant tumours, benign lesions and healthy skin based on the water content difference in cancerous and normal skin tissue can be performed using the proposed near field probes. To represent the EM properties of the cancer-affected skin, three types of lossy dielectric with different absorption level have been used to model malignant melanoma, healthy tissue and benign lesions. It has been shown that a malignant tumour with characteristic size $\lambda / 10$ can be discriminated with at least $6 \mathrm{~dB}$ amplitude and 50 degrees phase contrast from healthy skin and with more than $3 \mathrm{~dB}$ contrast from a benign lesion of the same size. These results open up the possibility for highly accurate early-stage melanoma detection. 